\title{
Environmental radiology assessment in Lahad Datu, Sabah
}

\author{
Yusof Siti Fharhana. ${ }^{1,}$, Wan Hassan Wan Muhamad Saridan ${ }^{1}$, Ramli Ahmad Termizi ${ }^{1}$, \\ Sahini Mohd Hilmi ${ }^{1}$, Mohd Sanusi Mohammad Syazwan ${ }^{1}$, Basri Nor Afifah ${ }^{1}$, and Abu \\ Hanifah Nor Zati Hani ${ }^{1}$ \\ ${ }^{1}$ Department of Physics, Faculty of Science, Universiti Teknologi Malaysia, 81310 UTM \\ Johor Bahru, Johor, Malaysia
}

\begin{abstract}
Monitoring terrestial gamma radiation is crucial to prepare a baseline data for environmental radiological protection. Radiological research was carried out in Lahad Datu, Sabah to obtain the radioactivity status and terrestrial gamma radiation level in the area. We measure the terrestrial gamma radiation dose rates and analyse the radioactivity concentration of primordial radionuclides for radiological risk assessment. We identified that the annual estimation of dose effective for public is below the public dose limit, $1 \mathrm{mSv}$ per year. Public and environment safety and health are remain secure. The obtained data and results can be used as reference for environmental radiology protection.
\end{abstract}

\section{Introduction}

\subsection{Research Background}

Due to its ionising power, high terrestrial gamma radiation dose may cause a detrimental effect to the public. The dilemma faced by public, governments and international radiation protection community on radiation health effects and risk of low doses has lead to the studies in the high background natural radiation area. Since the low level exposures may bring a stochastic effects to the public, the study of background radiation is extremely vital [1].

Public exposed to the radiation that occur from natural sources. Human beings were estimated to receive about $87 \%$ natural radiation. Therefore, it is important to assess environmental radiology for health and safety purpose [2].

Since the damage of Fukushima Daiichi nuclear plant tragedy, it is reported that $80 \%$ of radionuclides has entered the Pacific Ocean [3]. Therefore, this study should be conducted as in Peninsular Malaysia because the Sabah is surrounded by ocean, such as the South China Sea, Sulu Sea, the Celebes Sea and the Pacific Ocean.

\footnotetext{
*Corresponding author: sfharhana@gmail.com
} 


\subsection{Problem Statement And Research Objectives}

This research is conducted to measure the terrestrial gamma radiation in Lahad Datu district. This is also to prepare baseline data of terrestrial gamma radiation. Data collection in Peninsular Malaysia has been conducted but not in Lahad Datu, Sabah [18]. The accident at the Fukushima Daiichi Nuclear Power Plant in Japan in March 2011 resulted in the release of several hundred $\mathrm{pBq}$ of activity into the environment [5]. Therefore this research will identify the concentration of primordial radioanuclide for radiological health and safety assessment. Malaysia chose nuclear energy to guarantee supply beyond 2030 [6]. Baseline data is one of important aspect in assessing nuclear power plant site [7]. Hence, this research will build an isodose map of ionizing radiation in Lahad Datu for further reference.

\section{Methodology}

\subsection{The study area}

Lahad Datu district is located in southeastern Sabah, coordinated between latitudes $4^{\circ} 45^{\prime} \mathrm{N}$ and $5^{\circ} 30^{\prime} \mathrm{N}$, and longitudes $117^{\circ} 30^{\prime} \mathrm{E}$ and $119^{\circ} 15^{\prime} \mathrm{E}$. It covers an area of $6,501 \mathrm{~km}^{2}$ with 195,865 population in 2010 . This district is a great socio-economy contributor to Sabah State as it has the largest palm tree cultivation [8] where the world-class Palm Oil Industrial Cluster has been built here [9]. The world-class tourism spot, Danum Valley Conservation Area and Tabin Wildlife Reserve are also located in this district [9].

\subsection{Measurements of terrestrial gamma radiation dose rate}

The sampling points were determined based on the types of soil and geology in research area as the terrestrial gamma radiation is vary depends on the radionuclides concentration in soil [10]. The terrestrial gamma radiation dose rate was measured by using a survey meter (Ludlum19 micro R meter). Measurements were conducted at approximately $1 \mathrm{~m}$ above the surface of the land [11].

\subsection{Analysis of radioactivity concentration of primordial radionuclides}

The collected soil samples is prepared in Marinelli beaker for the analysis of natural concentration of radionuclide by using HPGe gamma spectrometer detector in Nuclear Laboratory, Faculty of Science, UTM. The analysis of gamma radiation spectrum is carried out by using gamma radiation counter system (GC2018-7500SL model) paired with Genie 2000 VI.3 software. The concentration of ${ }^{238} \mathrm{U}$ is calculated based on the energy peak of gamma ray of daughter radionuclides ${ }^{214} \mathrm{~Pb}$ and ${ }^{214} \mathrm{Bi}$ in the ${ }^{238} \mathrm{U}$ decay series. The concentration of thorium is calculated based on the energy peak of gamma rays of daughter radionuclides ${ }^{228} \mathrm{Ac}$ and ${ }^{208} \mathrm{Tl}$ in ${ }^{232} \mathrm{Th}$ decay series. ${ }^{40} \mathrm{~K}$ concentration is calculated based on the gamma ray emission peak of $1460.8 \mathrm{keV}$ energy [12].

\subsection{Radiological risk assessment}

After analysing the concentration of natural radioactivity, radiological risk assessment is carried out by calculating the Annual Estimation of Dose Effective, AEDE, the estimated probability of occurrence of cancer risk, $G$, the Radium Equivalent Activity, $R a_{e q}$, and the Hazards Index, $H_{e x}$. 


\subsection{Isodose mapping}

Isodose map of gamma irradiation in Lahad Datu is built based on terrestrial gamma radiation survey by using spatial mapping analysis software ArcGIS 9.3.

\section{Results and discussion}

\subsection{Terrestrial gamma dose rates}

A total of 86 sampling points were determined and the reading of gamma radiation dose rates was measured by using survey meter. Out of 86 sampling points, 10 soil samples labeled as $\mathrm{S} 1$ to $\mathrm{S} 10$ were taken for the analysis of the concentration of radioactivity. The soil samples were taken as representatives of different doses of dose levels; low and high doses relative to the environmental level. The highest gamma dose rate is $79.4 \mathrm{nGy} \mathrm{h}^{-1}$. The lowest terrestrial gamma dose rate is $6.1 \mathrm{nGy} \mathrm{h}^{-1}$. The mean terrestrial gamma dose rate is $44.7 \mathrm{nGy} \mathrm{h}^{-1}$ much lower than the mean terrestrial gamma dose rate proposed by UNSCEAR (2000), $57 \mathrm{nGy} \mathrm{h}^{-1}$.

\subsection{Radioactivity concentration of primordial radionuclides}

Table 1 illustrates the radioactivity concentration of primordial radionuclides, $\mathrm{C}$ in soil samples. The mean value of $\mathrm{C}_{\mathrm{U}-238}, \mathrm{C}_{\mathrm{Th}-232}$ and $\mathrm{C}_{\mathrm{K}-40}$ is $42.6 \mathrm{~Bq} \mathrm{~kg}^{-1}, 77.7 \mathrm{~Bq} \mathrm{~kg}^{-1}$ and 810.9 $\mathrm{Bq} \mathrm{kg}{ }^{-1}$ respectively. It was assumed that the high value of potassium concentration is due to the contribution of potassium content in fertilizer used in palm tree cultivation.

Table 1: Radioactivity concentration of ${ }^{238} \mathrm{U},{ }^{232} \mathrm{Th}$ and ${ }^{40} \mathrm{~K}$.

\begin{tabular}{|c|c|c|c|}
\hline Sample & $\begin{array}{c}\mathbf{C}_{\mathrm{U}-238} \\
\left(\mathrm{~Bq} \mathrm{~kg}^{-1}\right)\end{array}$ & $\begin{array}{c}\mathbf{C}_{\text {Th-232 }} \\
\left(\mathrm{Bq} \mathrm{kg}^{-1}\right)\end{array}$ & $\begin{array}{c}\mathbf{C}_{\mathrm{K}-40} \\
\left(\mathrm{~Bq} \mathrm{~kg}^{-1}\right)\end{array}$ \\
\hline $\mathrm{S} 1$ & 46.2 & 87.1 & 961.0 \\
\hline $\mathrm{S} 2$ & 48.8 & 78.4 & 817.0 \\
\hline $\mathrm{S} 3$ & 28.5 & 46.7 & 473.0 \\
\hline $\mathrm{S} 4$ & 47.9 & 80.0 & 764.0 \\
\hline $\mathrm{S} 5$ & 58.1 & 110.7 & 1225.7 \\
\hline $\mathrm{S} 6$ & 43.2 & 67.2 & 747.0 \\
\hline $\mathrm{S} 7$ & 57.0 & 107.9 & 900.0 \\
\hline $\mathrm{S} 8$ & 55.3 & 105.4 & 1200.0 \\
\hline $\mathrm{S} 9$ & 18.7 & 34.0 & 426.0 \\
\hline $\mathrm{S} 10$ & 22.7 & 59.3 & 595.2 \\
\hline $\begin{array}{c}\text { Mean } \\
\text { concentration }\end{array}$ & 42.6 & 77.7 & 810.9 \\
\hline
\end{tabular}




\subsection{Radiological risk assessment}

Using equation (1), the annual effective dose equivalent, AEDE to the public was calculated (UNSCEAR, 2000).

$$
\text { AEDE = Dose rate } n G y \mathrm{j}^{-1} \times 24 \mathrm{hrs} \times 365 \text { days } \times 1 \text { OF } \times 0.7 \mathrm{~Sv} \mathrm{~Gy}^{-1} \times 10^{-6}
$$

Annual Estimation of Dose Effective, AEDE is $0.44 \mathrm{mSv}$ per year lower than public dose limit, $1 \mathrm{mSv}$ per year.

The probability of the risk of cancer, $G_{r}$ is estimated by using equation (2). The risk factor, $R$ is $0.05 \mathrm{~Sv}^{-1}$ and $H$ is the AEDE value [13].

$$
G_{r}=R . H
$$

The estimated probability of the risk of cancer, $G_{r}$ is 0.02 probability per year per person. The value of the probability of cancer risk is too small to be considered as radiological hazard to the public in the study area.

Radium equivalent activity, $R a_{e q}$ is calculated by using equation (3) [14].

$$
R a_{e q}=\mathrm{C}_{\mathrm{U}-238}+1.43\left(\mathrm{C}_{\mathrm{Th}-232}\right)+0.0077\left(\mathrm{C}_{\mathrm{K}-40}\right)
$$

Radium equivalent activity, $R a_{e q}$ is $160 \mathrm{~Bq} \mathrm{~kg}^{-1}$ which is less than the recommended limit of concentration for TENORM material which is $370 \mathrm{~Bq} \mathrm{~kg}^{-1}[15]$.

Equation (4) is used to calculate the hazard index, $H_{e x}[15]$.

$$
H_{e x}=\frac{C_{U-238}}{370}+\frac{C_{T h-232}}{259}+\frac{C_{K-40}}{4810} \leq 1
$$

The value of $H_{e x}$ must be lower than 1 which equivalent to the maximum recommended limit of radium activity, $370 \mathrm{~Bq} \mathrm{~kg}^{-1}$ [16]. In this study, the $H_{e x}$ value is 0.58 which is lower than 1 .

\subsection{Isodose mapping}

Figure 1 exhibits an isodose map based on the survey of gamma radiation in the field. The map contour generated in the isodose map based on the surveys are still rough where there is a large gap between the contour for the less observed area. This is because the accuracy of the interplotation data is proportional to the distance between dose rate survey points [17]. By following the dose rate range of isodose maps of Peninsular Malaysia [18], Figure 1 shows a very low dose rate in research area which indicates a safe environment for public. 


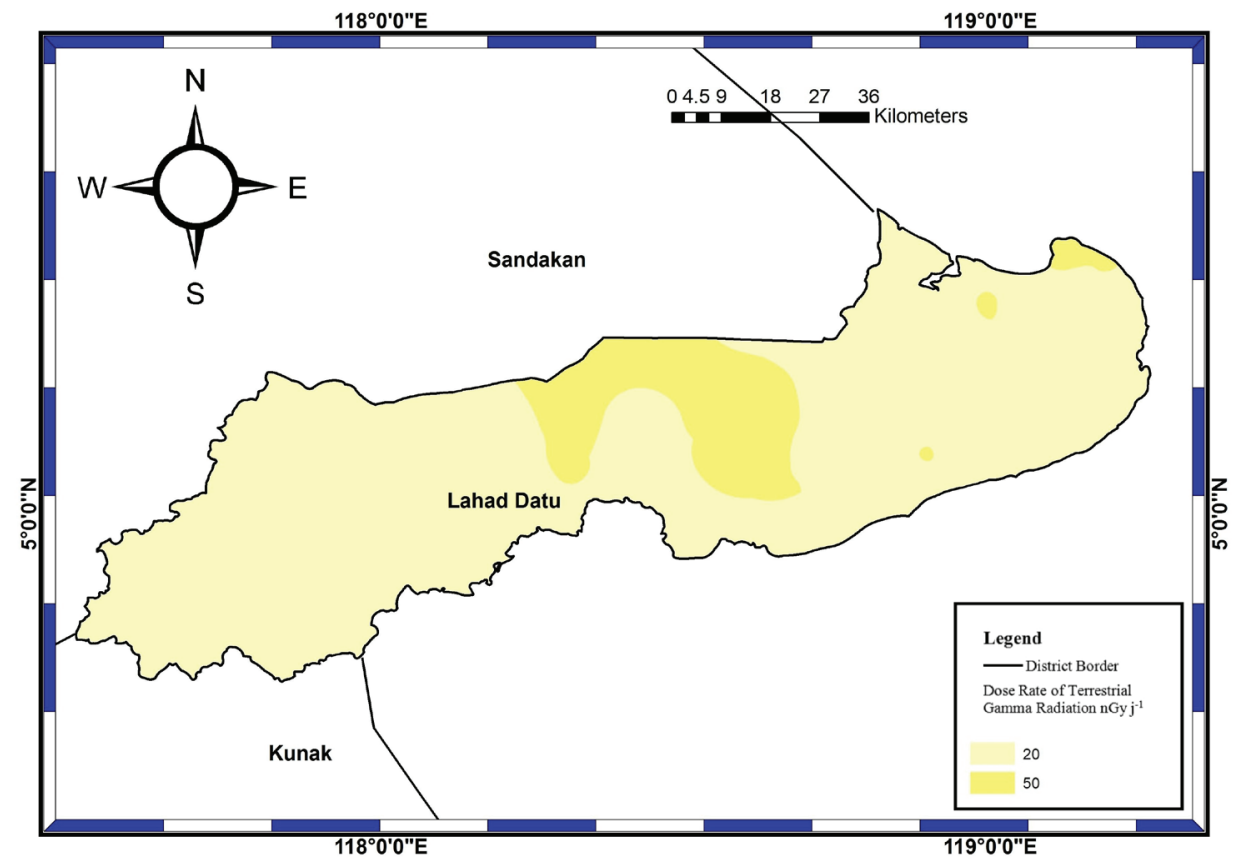

Figure 1: Isodose map based on gamma radiation survey in study area.

\section{Conclusion}

The level of gamma radiation in the environment is too small to cause an acute effect and macro stochastic effect. We identified that the annual estimation of dose effective for public is below the public dose limit, $1 \mathrm{mSv}$ per year. Therefore, public and environment safety and health are remain secure. The obtained data and results from this study can be used as reference for environmental radiology protection.

The authors wish to acknowledge the Ministry of Science, Technology and Innovation (MOSTI) and Universiti Teknologi Malaysia for supporting this research by providing R.J130000.7926.4S109 grant.

[1] M. Sohrabi, World high background natural radiation areas: Need to protect public from radiation exposure, 50, 166-171, (2012).

[2] N. Ahmad, M. S. Jaafar, M. Bakhash, M. Rahim, An overview on measurements of natural radioactivity in Malaysia, 8, 136-141, (2015).

[3] O. Evrard, J. P. Lepage, Y. Onda, O. Cerdan, S. Ayrault, Radiocesium transfer from hillslopes to the Pacific Ocean after the Fukushima Nuclear Power Plant accident: A review, 148, 92-110, (2015).

[4] Department of Agriculture Sabah, Hectareage of industrial crops by districts and types of crops, Sabah, (2014), retrieved on 22 April 2016 from http://ww2.sabah.gov.my/

[5] Barletta, W. A., Stoop J, O’Hara C., Bailiff, I. H., Hermanspahn, N., Hugtenburg, R.,

Alcock, R., Covaci, A., Barcelo, D., Gan, J. and Karlsson, (2016). 5 years after Fukushima — insights from current research. A virtual special issue featuring free access to impactful research from a multidisciplinary perspective.

[6] Basri, N. A. and Ramli, A. T., (2012). Selection of possible candidate area for nuclear power plant in Johor, Malaysia. Nuclear and Related Technologies, 9 (1). pp. 56-63. ISSN $1823-0180$ 
[7] Saleh, M. A., Ramli, A. T., Alajerami Y., Mhareb M. H. A., Aliyu A. S., Gabdo H. T., Garba N. N. (2014). Assessment of radiological health implicat from ambient environment in the Muar district, Johor, Malaysia. Radiation Physics and Chemistry. 103, 243-252.

[6] Lahad Datu District Office, Latar Belakang PDLD, retrieved on 11 Jun 2015, from http://ww2.sabah.gov.my/

[7] Z. Wang, Natural radiation environment in China, 1225, 39-46, (2002).

[8] UNSCEAR. United Nations Scientific Committee on the Effect Atomic Radiation (2000). Sources and Effects of Ionizing Radiation. UNSCEAR Report on The General Assembly. New York : United Nations.

[9] G. Wallova, N. Kendler, G. Wallner, Monitoring of radionuclides in soil and bone samples from Austria, 107, 44-50, (2012).

[10] International Commission on Radiological Protection ICRP 60, (1990).

Recommendations of the international commission on radiological protection. In: ICRP Publication 60, Annals of the ICRP. Pergamon Press,

Oxford.

[11] Y. Orgun, N. Altınsoy, S.Y. Sahin,Y.Gungor, A.H. Gultekin, G. Karahan, Z. Karacık, Natural and anthropogenic radionuclides in rocks and beach sands from Ezine region ( $\mathrm{C}$ - anakkale ), Western Anatolia, Turkey, 65, 739-747, (2007).

[12] E. O. Agbalagba, G. O. Avwiri, Y. E. Chad-umoreh, g -Spectroscopy measurement of natural radioactivity and assessment of radiation hazard indices in soil samples from oil fi elds environment of Delta State , Nigeria, 109, 64-70, (2012).

[13] A. Sh.Aydarous, S. Zeghib, M. Al-Dughmah, Measurements of natural radioactivity and the resulting radiation doses from commercial granites, 142, 363-368, (2010)

[14] A. T. Ramli, M. S. M. Sanusi, N. A. Basri, Final Report; Isodose Mapping of Terrestrial Gamma Radiation in Peninsular Malaysia, UTM Skudai, (2013) 